\title{
Annual Report and Editorial Commentary for The Accounting Review
}

\author{
Steven J. Kachelmeier \\ University of Texas at Austin
}

Prepared June 2010

I am grateful for helpful feedback and suggestions from Linda Bamber, Jean Bedard, and Tracie Majors on an earlier version of this report, though I assume full responsibility. I also thank Mary Capps for painstakingly checking the current affiliations in the Appendix of ad hoc reviewers. 


\section{Annual Report and Editorial Commentary for The Accounting Review \\ Steven J. Kachelmeier, Senior Editor \\ University of Texas at Austin}

\section{INTRODUCTION}

I am pleased to submit the second Annual Report for The Accounting Review under the new content guidelines adopted by the Publications Committee and Executive Committee of the American Accounting Association (AAA). From the feedback I have heard, the new format has succeeded in creating a more open environment of full disclosure and accountability to our constituents. It is also a learning experience for the senior editor, providing useful feedback on our processes and decisions. As I did last year, I am taking the liberty of interjecting a liberal dose of editorial commentary along with the statistics, subject to the caveat that my interpretations are opinions with which others may disagree.

Section II below updates last year's qualitative commentary on the editorial process followed by The Accounting Review under the current regime. Section III then follows with the tabular data requested by the AAA Publications Committee, along with some supplemental data I have provided to clarify certain aspects of these tables. Section IV closes with some personal notes of thanks and remembrances.

\section{UPDATES TO THE ACCOUNTING REVIEW EDITORIAL PROCESS}

To avoid repetition, I refer the reader to last year's report (Kachelmeier 2009) for a description of the editorial process followed by The Accounting Review. This year's description is limited to an update of new developments and changes in process that have occurred over the fiscal year ending May 31, 2010.

One important update is that several coeditors of The Accounting Review have generously agreed to increase their allocation beyond the maximum of three new submissions per month that 
I promised upon establishing our editorial team. Especially for financial-archival manuscripts that constitute so many of our submissions (as reported later), the coeditors who agreed to take on a bit more generally now handle four and sometimes five new submissions per month. As a consequence, my proportion of the total decision letters has declined from last year, in which I wrote 345 (48.0 percent) of the 719 decision letters sent from June 1, 2008 to May 31, 2009. For the fiscal year of this report ending May 31, 2010, I wrote 205 (30.5 percent) of the journal's 673 decision letters, delegating slightly more than two-thirds of our decisions to coeditors whose expertise aligns more closely with the area of the submission. Another reason for the decline in my share of the decision letters is that I wrote most of the decision letters for "transition" manuscripts that were in process at the time the current editorial term began on June 1, 2008. Almost all of those manuscripts have now cleared the system, so current decisions, whether for new submissions or for revisions, tend to be for manuscripts initially submitted under the current regime and assigned to one of the current editors from the onset.

While my decision-letter volume has subsided somewhat, it remains my preference to centralize the reviewer selection process. With the help of my truly outstanding doctoral research assistant, Tracie Majors, I review each new submission and Tracie's search results from various databases to find two well-qualified and independent reviewers, proposing those names to the assigned editor (if other than me). A centralized reviewer selection process helps to ensure uniformity of reviewer credentials across submissions, in addition to facilitating the coordination problem of avoiding multiple requests to the same reviewer at the same time (although this is sometimes unavoidable for invited revisions). Given the demands on our most frequently requested reviewers, a typical strategy is to choose one reviewer from TAR's Editorial Advisory and Review Board (or a substitute of similar seniority) and one other reviewer, likely more 
junior, whom we ask less often. Other times we try to diversify, such as choosing a reviewer from each of two areas relevant to the submission under consideration. To avoid sending signals, we use a random algorithm to ensure that the labeling of "Reviewer A" and "Reviewer B" is completely arbitrary.

Over the year, we found ourselves asking some ad hoc reviewers about as many times as we would ask an Editorial Board member, so in fairness, I generally invited those individuals to join the Board if they had submitted several high quality reviews on a timely basis. Thus, TAR's Editorial Advisory and Review Board has grown from 118 members at the time of our first issue (January 2009) to 129 members as of the date of this report. An Editorial Board of 129 members might seem large (as recently as 2005 , there were only 68 members), but I am continually amazed at how difficult it is to find "open" Editorial Board members who do not already have a review assignment in hand. Sometimes "Professor X" is the obvious choice to review a new submission closely related to X's expertise, but if we recently asked Professor X to review a different manuscript, we generally look elsewhere. In short, we do the best we can to optimize reviewer selection, considering both relevance and availability.

Even with 129 Editorial Board members, it would be highly misleading to infer that these 129 experts write all the reviews. For the fiscal year ending May 31, 2010, TAR asked an additional 453 ad hoc reviewers, as named and thanked in the Appendix, to evaluate one or more submissions. Thus, the journal's editorial decisions during the fiscal year ending May 31, 2010 were guided by $582(=453+129)$ different experts across a wide variety of topical and methodological interests. The diversity inherent in 582 different reviewers is consistent with TAR's mission. 
Given the reviewer demands of a journal with over 500 new submissions per year (not even counting revisions), several people have asked me why TAR persists with using two different reviewers for each new submission, especially given that some of our competitors use only one. To be sure, a two-reviewer system is costly, both in reviewer resources and in time (by construction, we are always waiting on the later of the two reviewers). Ex post, authors often sense that it is more difficult to address the concerns of two reviewers than it would be to address a single reviewer's concerns, especially if they could pick which reviewer to keep and which to discard. But therein lies the point. Editors have to select reviewers ex ante, and given that reviewers often disagree (Blank 1991; Gilliland and Cortina 1997; Lynch 1998), both the editor and author gain some protection by getting two draws from the distribution instead of just one. Thus, though authors sometimes see it differently, I honestly see a two-reviewer system as being in the author's best interest, at least ex ante. When two reviewers forward different recommendations, editorial judgment becomes critical. The general decision model employed by the current editorial team for split reviews is to consider whether the negative reviewer has identified a "fatal flaw" that is inherent to the study. If so, we reject, but otherwise we generally move forward, even if that means overruling a reviewer who recommends rejection. Along that line, another benefit of a two-reviewer system is that it provides useful feedback to the reviewers, especially those newer to the process. That is, each reviewer can calibrate his/her assessment against that of the other reviewer, as we send the reviewers copies of both reviews along with a blind copy of the editorial decision letter.

A new development this year is that I have started to enforce the expectation that revisions should be submitted within a year of the decision letter inviting the revision. While it has long been part of TAR's published Editorial Policy, it is my understanding that the "one-year 
rule" was rarely enforced prior to 2009. Beginning June 1, 2008, however, we started noting this policy explicitly in decision letters inviting a revision. Thus, when the one-year anniversary arrives with no revision in hand, I generally write an email to the submitting author offering one more month (essentially, a grace period) to revise and resubmit. Six times during the fiscal year ending May 31, 2010, after the $13^{\text {th }}$ month elapsed with no revision, I informed the author of my intent to close the file. This might seem harsh, but if we are serious about lessening the time it takes from an initial submission to the ultimate decision, part of that responsibility lies with authors. Moreover, it is my experience that very old revisions fare worse in the review process, as they face the risk of obsolescence (research tends to have a short "shelf life").

There are two caveats to my willingness to enforce the policy allowing one year to revise and resubmit. First, sometimes an author will reply back to my “one-year anniversary” email with an explanation of extenuating medical or personal circumstances that prevented a more timely revision, and I try to take those circumstances into account in reaching a reasonable accommodation to which the author and I can agree. Second, I have not enforced the one-year deadline for revisions invited before the current editorial term began on June 1, 2008, as earlier decision letters did not state that deadline explicitly. By now, however, I hope that the vast majority of those revisions are behind us.

For several other aspects of TAR's editorial process, I encourage the reader to see my previous year's report (Kachelmeier 2009). ${ }^{1}$ It is my general understanding from the AAA Publications Committee that each new senior editor will begin his/her term with a report that provides a more comprehensive description of his/her editorial process and philosophy, as I tried

\footnotetext{
${ }^{1}$ In addition to last year's annual report, for my personal thoughts on the review process in accounting journals, see Kachelmeier (2004).
} 
to do last year, followed by updates in subsequent years of the editorial term, but without repeating points that have not changed.

\section{EDITORIAL AND PUBLICATION STATISTICS}

This section of the report provides specific tables requested by the AAA Publications

Committee, along with supplemental data for clarification. To differentiate the supplemental material, each table first reports the specific data requested by the Publications Committee, followed by any supplemental data explained in the discussion of each table.

\section{Table 1: Annual Activity Summary}

Table 1, Panel A reconciles TAR's workflow for the prior and current journal year ending May 31, 2009 and 2010, respectively. The volume of new submissions is down somewhat, from 557 last year to 502 in fiscal 2010. My best guess is that this difference does not reflect a reversal of TAR's general trend of increasing submissions, but rather reflects a "blip" of an exceptionally large number of new submissions in the summer months of 2008 from authors who did not want their manuscripts to overlap two editorial regimes. This conjecture is supported by the fact that $T A R$ received only 163 new submissions during the first five months of calendar 2008 (i.e., the last five months of former Senior Editor Dan Dhaliwal's term), as compared to 238 new submissions during the first five months of 2009 and 232 new submissions during the first five months of 2010. I suspect that we may experience a similar downturn in spring of 2011 for authors waiting for the new regime to begin on June 1, 2011. Authors should be aware, however, that editorial transition issues are not as complex as they might appear. The current regime will continue to choose reviewers through May 31, 2011, but the next regime will likely be making most of the decisions for manuscripts submitted just before the end of the fiscal year, after the reviews arrive sometime in June or July. 
As was the case last year, a limitation of Table 1, Panel A is that logging all submissions results in double counting some manuscript files, to the extent that TAR often receives two or more versions of the same manuscript within the same year, following invitations to revise and resubmit. For the journal year ending May 31, 2010 (2009), the 673 (719) total decisions reflect 615 (646) unique manuscript files, with the differences representing revisions of manuscripts for which previous decisions inviting revision had already been logged within the same fiscal year.

Table 1, Panel B is supplemental, reporting submissions by calendar year instead of the journal's fiscal year that ends on May 31. The calendar year tallies were reported prior to 2008, so Panel B facilitates comparison over time. It corroborates that, notwithstanding the temporary surge in new submissions that occurred shortly after June 1, 2008, the general trend of submissions has been steadily increasing for several years. Specifically, over the past decade, TAR's submission volume has approximately doubled.

\section{Table 2: Annual Outcome Summary}

\section{Table 2, Panel A: Outcomes by Fiscal Year}

Table 2, Panel A tallies the outcomes for all decisions reached during the fiscal year. As requested by the Publications Committee, this panel also reports two "acceptance rates." The first rate in column (e) divides the number of acceptances or conditional acceptances by the number of final accept or reject decisions. The second rate in column (f) divides the same (conditional) acceptances by the total number of decisions reached. The difference between the two denominators reflects invitations to revise and resubmit. Accordingly, the first rate somewhat overstates and the second rate somewhat understates the "true" acceptance rate. As in last year's report, Table 2 includes “conditional” acceptances in the acceptance category, as we have yet to reject any manuscript that has reached "conditional acceptance" status. 
As with Table 1, a limitation of Table 2, Panel A is that the total number of decisions in any given journal year includes some manuscript files for which multiple decisions are made within the same year, due to invitations to revise and resubmit. If one divides the number of acceptances by the number of unique manuscript files processed (646 and 615 for the years ending May 31, 2009 and 2010, respectively), the resulting estimated acceptance rates are 12.5\% $(=81 / 646)$ for fiscal 2009 and $10.2 \%(=63 / 615)$ for fiscal 2010 , bearing in mind that the denominator for both years includes several open files awaiting further revision, for which final decisions have yet to be reached.

The reader might have cause for concern in noting that our total number of acceptances is down from 81 last year to 63 this year. The estimated acceptance rates also reflect this downturn. However, I do not perceive any substantive change in our editorial standards for acceptance. One reason for the decline reflects my attempt to build a modest "buffer" of forthcoming articles by taking special efforts to expedite some near-acceptance manuscripts shortly after the current editorial term began on June 1, 2008. Before that time, TAR was essentially operating on an issue-to-issue basis, meaning that the articles accepted for publication at the time of the deadline for the next issue became the articles published in that issue. This process can create imbalances due to the sometimes cyclical nature of the flow of submissions and revisions, so I decided early on that I would like to have one or two issues "in waiting" at the time of each issue deadline, providing a buffer to help smooth out the cyclical variation. Accordingly, during the last half of 2008, my coeditors and I built a buffer of approximately 15-20 forthcoming articles at the conditional acceptance stage, and we have held that buffer roughly constant ever since.

A second reason for the downturn in acceptances from 81 last year to 63 this year is a bit embarrassing, but I will provide full disclosure. In May of 2010, I encountered a personal 
backlog, due to my end-of-semester teaching responsibilities, among other priorities. Thus, some conditional acceptance letters drafted by my coeditors in April or May did not get sent out until June, as I always read and provide my own comments (and usually a marked copy) on all accepted manuscripts before sending out the decision. Ever the good accountant, I strictly applied a May 31 cutoff in preparing Table 2, but the reader should be aware that we sent out ten additional acceptance letters in the first half of June, 2010. Including those ten would have brought the fiscal 2010 acceptance total to 73 instead of 63 . The good news is that I get to count them next year.

To put the number of acceptances in perspective, the reader should consider our capacity constraint. So long as journals continue to publish bound hard-copies, there are only so many articles that can fit in a bound issue. Effective 2008, TAR has published six times per year. In my experience, I can fit up to 12 articles in each issue. Thus, if we fill the journal to capacity, we have room for $12 \times 6=72$ articles per year, one of which goes automatically to the Presidential Scholar Lecture. For the most part, we have been filling the journal to its practical capacity, which happily coincides with what I perceive to be a reasonable, productive acceptance rate that publishes good research while maintaining a high quality standard. I cannot make any promises about our ability to sustain full-capacity production, as an editor never knows what is coming next, but I think the journal is in good health.

\section{Table 2, Panel B: Final Outcome Resolution for All New Submissions}

New this year is supplemental Panel B to Table 2, reflecting what I think is an excellent suggestion from AAA Publications Committee member Bob Kaplan to calculate the journal's "acceptance rate" in a different way. As I understand the suggestion, if one views any given year's new submissions as the population from which articles can be accepted, then in 
subsequent years, after most of the revisions have been processed, one can tally how many of that year's new submissions were accepted, how many were rejected, and how many remain pending due to outstanding invitations to revise. Table 2, Panel B reports this supplemental format for the 557 new submissions received during the journal year ending May $31,2009 .^{2}$ Of these, $45(8.1 \%)$ have been accepted through May 31, 2010, $442(79.4 \%)$ have been rejected, and the remaining 70 manuscripts (12.6\%) are still outstanding as of May 31, 2010 due to pending revisions. These statistics provide a useful floor and ceiling for $T A R$ 's acceptance rate: for fiscal 2008-2009, the acceptance rate can be no lower than $8.1 \%$, as those manuscripts have already been accepted, and can be no higher than $20.6 \%$ if all remaining pending revisions from fiscal 2008-2009 are eventually accepted. Of course, it is unrealistic to assume that either none or all of the pending revisions will be accepted. My best estimate is that splitting the difference between the two numbers (an estimated acceptance rate of 14.4\%) comes materially close to our true acceptance rate for the first year of operations under the current editorial regime. I will provide a follow-up table next year.

\section{Chart 1: Histogram of Editorial Rounds and Outcomes}

Chart 1 provides a histogram of decision outcomes by round for the journal year ending May 31, 2010. As I did last year, I am taking the liberty of reporting more detail than that requested by the Committee, showing separate bars for "revise" and "uncertain" invitations as well as separate bars for "contribution" and "validity" rejections. The 475 first-round decisions in Panel A of Chart 1 differ from the 502 new submissions reported in Panel A of Table 1 because Chart 1 includes 98 new submissions "in process” as of June 1, 2009 and excludes 125 new submissions for which a decision had not yet been reached as of May 31, 2010.

\footnotetext{
${ }^{2}$ Table 2, Panel B does not report outcomes for new submissions during the journal year ending May 31, 2010, as too many of those new submissions are awaiting a decision as of May 31, 2010 to make the statistics meaningful.
} 
Chart 1, Panel A shows that most first-round manuscripts are rejected because they lack a sufficient incremental contribution for The Accounting Review. Ever since we started logging rejection decisions as being based primarily on contribution issues or validity issues, I have been struck by the fact that the former category is more than twice as frequent as the latter. Indeed, my sense of the modal first-round review report that recommends rejection is that it contains wording similar to, "While this study appears to have been competently executed, it does not provide much new insight relative to what we already know from the extensive prior literature in this area." Put simply, following the bandwagon in a well-researched area is not necessarily a path to success in a top-tier journal.

Under the current editorial regime, The Accounting Review has employed two revision categories: (1) standard "revise-and-resubmit" letters, and (2) "uncertain" letters. Both outcomes allow the author to revise, but an "uncertain" letter indicates that the outcome risk is higher than usual for an invitation to revise, such that the path to a successful revision is unclear. When sending an "uncertain" letter, we encourage a careful assessment of whether the author sees an effective way to address the concerns raised, and if not, that submission elsewhere might be best for the author from a cost-benefit perspective. The easiest way for an author to tell which kind of letter s/he has received is that an "uncertain" letter asks for an email reply indicating whether or not the author intends to revise and resubmit. While some might reason that an author should always exercise an option to revise, the honest intent of an "uncertain" letter is that the decision is unclear from the editor's perspective, as a multiple-round rejection can be worse for the author than a first-round rejection. As Chart 1 indicates, most revision letters are of the standard "revise-and-resubmit" variety, but we try to use the more cautious "uncertain" wording when appropriate. To avoid misunderstanding, I should clarify that even a standard "revise-and- 
resubmit" letter conveys outcome risk; it is only the degree of that risk that differs between the two revision categories.

Chart 1 indicates that the relative odds of success increase substantially in the second round and beyond. By the time a manuscript reaches the third or fourth round (Panel C), most outcomes are acceptances, as should be the case for manuscripts that have advanced to this stage. Still, nothing is guaranteed, as is evidenced by the seven rejections in Chart 1, Panel C. As an aside, the vast majority of the decisions tallied in Chart 1, Panel C are for third-round manuscripts, with only nine that went to the fourth round. We did have one fifth-round manuscript within the journal year ending May 31, 2010, which, fortunately, was accepted for publication.

\section{Table 3: Submissions and Acceptances by Subject Area and Research Method}

Perhaps the most interesting statistics are in Table 3, which categorizes submissions and acceptances by primary subject area (Panel A), primary method (Panel B), and subject areas crossed with methods (Panel C). Very similar to last year, all three panels show that the proportion of acceptances by area is nearly identical to the proportion of submissions by area. Contingency table tests fail to reject the null hypothesis of equivalent submission and acceptance proportions by subject area $\left(\chi_{\mathrm{df}=7}^{2}=5.74 ; p>0.50\right)$ or by method $\left(\chi_{\mathrm{df}=5}^{2}=6.35 ; p=0.27\right) .^{3} \mathrm{As}$ was the case last year, if any area might be able to state a case for underrepresentation relative to submissions, it would be those who conduct financial-archival research (45\% of submissions and $37 \%$ of acceptances). That said, a journal editor would probably take issue with that statement

\footnotetext{
${ }^{3}$ To address the possibility that small cell sizes in the less frequent categories might be distorting the statistics, I repeated both the subject area and methodological contingency table analyses after combining the "governmental/NFP," "international," "systems," and "other" subject areas into a combined "other" subject area category and after combining the "field/case," "survey," and "other" methods into a combined "other" methodological category. Results continue to fail to reject the null hypothesis of equivalent submission and acceptance percentages for both subject areas $\left(\chi_{\mathrm{df}=4}^{2}=4.09 ; p=0.39\right)$, and methods $\left(\chi_{\mathrm{df}=3}^{2}=4.09 ; p=0.25\right)$.
} 
(justifiably) if this editorial were subjected to the review process, given the lack of statistical significance as reported above.

The broader point is that one cannot draw inferences about acceptance rates by area (a ratio) by looking at what journals publish (the numerator of that ratio). ${ }^{4}$ Table 3 sheds insight by reporting our denominators in terms of submissions by area, and I submit that these data add an important qualification to Tuttle and Dillard's $(2007,398)$ assertion that the research and publication process in the United States is "privileging financial accounting research competing for prestige journal space." While Tuttle and Dillard (2007) (and others) may well be correct in asserting that financial-archival research is commanding an ever larger share of the pie, Table 3 suggests that The Accounting Review is a reflection of that phenomenon, not the cause.

In raising this point over the past year regarding the similar statistics reported in my previous annual report (Kachelmeier 2009), I have often heard the counterargument that submissions by area are endogenous (to use an empirical-archival term), reflecting authors' preferences and beliefs regarding their likely prospects at any given journal. Put simply, researchers in underrepresented areas will not submit to The Accounting Review if they perceive that they will not get a fair shake at The Accounting Review. I understand this argument, but I also find it to be circular. It is difficult for me to understand how any journal can be criticized for not publishing research it does not receive.

To be sure, inclusive journals should take steps to signal openness to the scholarly community, such as through its editorial board appointments and editors. I will leave the reader to evaluate the diversity of our 129 editorial board members and the additional $453 \mathrm{ad} \mathrm{hoc}$

\footnotetext{
${ }^{4}$ Merchant (2010) is a classic case in point, drawing inferences about various journal specializations (and implied biases) from the nature of the articles they publish. One cannot deny that different accounting journals publish different frequencies of articles in various areas, as Merchant (2010) demonstrates persuasively, but analyses of journal content cannot differentiate the possibility of editorial biases from the broader phenomenon of self-selection by submitting authors.
} 
reviewers named in the Appendix. As for editors, I am joined by a diverse set of outstanding coeditors such as Shannon Anderson (expertise in field studies), Jim Hunton (expertise in accounting information systems), and Tom Omer (expertise in taxation). The rest seems up to the community. If, at some point, a future Table 3 shows an imbalance between submissions by area and acceptances by area, then we can engage a different debate as to the causes of that imbalance. But until then, I think Table 3 indicates that we are running a fair game, with all areas having roughly equal prospects of success. As the acceptance-rate data indicate, those prospects are not very high ex ante. But the same high standards of quality and rigor apply to all.

\section{Table 4: Author Affiliations}

Table 4, Panel A tallies the number of articles corresponding to each university for which at least one (co)author published an article in Volume 84 (calendar 2009) or Volume 85 (calendar 2010) of The Accounting Review. Articles written by k coauthors are attributed 1/k to each author's affiliation, and if an author lists two affiliations, half of that author's $1 / \mathrm{k}$ share is allocated to each affiliation. As I did last year, I list the institutions in Table 4, Panel A in descending order of the number of articles published. ${ }^{5}$ However, the intent of Panel A is most certainly not to compare universities in terms of research productivity. A recent study by Coyne et al. (2010) reports a more comprehensive analysis along that line. Rather, the point of Table 4, Panel A is to document the diversity of TAR's authors. Fully 131 different institutions were represented in 136 research articles published in The Accounting Review over the past two years. That seems pretty diverse to me.

\footnotetext{
${ }^{5}$ The fact that the University of Texas at Austin happens to be listed first this year (6.08 articles, or $4.5 \%$ of the two-year total) gives me a good opportunity to clarify that, by policy, a TAR coeditor never serves as editor on one of his/her own colleague's manuscripts. The 6.08 coauthor-adjusted TAR articles for the University of Texas at Austin over the past two years reflect nine different authors across a variety of topics and methods.
} 
Table 4, Panel B reports data on international diversity, tallying frequency counts for both submissions and acceptances for U.S. authors and non-U.S. authors. Separate columns report these data for the journal year ending May 31, 2010 and for the two-year cumulative totals combining this year and last, with the aggregate statistics reducing the cumulative submission count for files submitted in both years due to revision. Authors from non-U.S. affiliations comprise $27.0 \%(26.7 \%)$ of the fiscal 2010 (cumulative) submissions, and $20.1 \%(19.8 \%)$ of the acceptances. A contingency table test does not reject the (two-tailed) null hypothesis of equal submission and acceptance percentages of U.S. vs. non-U.S. authors for fiscal 2010 $\left(\chi_{\mathrm{df}=1}^{2}=1.19 ; p=0.28\right)$, but the statistic becomes marginally significant in the more powerful cumulative test $\left(\chi_{\mathrm{df}=1}^{2}=3.01 ; p=0.08\right)$. My hunch is that non-U.S. authors are probably underrepresented a bit in acceptances relative to submissions, but as I indicated last year, I honestly do not perceive any such underrepresentation as an overt bias against non-U.S. authors. Rather, I suspect that the factors that influence reviewer assessments of manuscript quality are correlated to some extent with the U.S. / non-U.S. categorization. To avoid misunderstanding, please note that this conjecture is a comment on the distribution, not a generalization about non-U.S. authors. For the vast majority of our submissions, I have discerned no systematic quality differences between U.S. and non-U.S. authors, and indeed, current data indicate that about one out of every five articles published in TAR is written by a non-U.S. author. My comment applies only to the tails of the distributions.

\section{Table 5: Processing Time}

Table 5 reports processing time data for the 673 decisions reached from June 1, 2009 through May 31, 2010, defining "processing time" as the number of days from the submission to the date my assistant, Mary Capps, sends the decision letter. Our overall processing time has not 
improved since last year - in fact, the average is up from 81 days last year to 86 days this year. I was curious to learn why it takes nearly three months to reach an (average) editorial decision, so I dug a bit deeper by first determining the later reviewer for each reviewed submission and then calculating the average review time for that later reviewer. Calculating the review time for the later of the two reviewers is appropriate because a two-reviewer system is subject to somewhat of a "weakest-link" problem - even if the first reviewer is timely, a decision based on two reviews cannot proceed until the second review arrives.

For the journal year ending May 31, 2010, the later of the two reviewers took an average of 55 days to return his/her review - call it two months. If our average total turnaround time is about three months, this means that the typical manuscript is out for review for two months, with an additional month for (1) initial administrative processing to log the submission in our system and check for previous, related submissions, (2) the initial "pre-review" by my research assistant and by me to identify potential reviewers, (3) reviewer clearance with the assigned editor, (4) processing invitations to both reviewers and following up, as necessary, (5) finding and sending invitations to alternative reviewer(s) if the initially invited reviewer(s) decline, (6) editorial processing of the reviews, (7) editorial processing of the manuscript, (8) formulating and writing the decision letter, (9) senior editor reading of a coeditor's decision letter and consultation, if applicable, and (10) administrative processing of the decision letter and corresponding statistics for our databases. Yes, I know this ten-point list sounds a bit defensive, but my intent is to communicate that there are many things to do for each file, and especially when other demands (like teaching) are present, it is difficult to get the total non-review time materially lower than a month, though we try and are successful to varying degrees at different 
times of the year. (The Holiday season is especially problematic - authors probably should not expect a very quick turnaround when submitting a manuscript on December 15.)

Regarding review time, some might advise reaching a decision based on one review if the second review is not in hand within two months, and indeed, that was my intent when I started the term. Especially this year, however, my coeditors and I have tended to wait for both reviews, even if that means a turnaround time that exceeds what we like to see. It is easy to favor a one-reviewer decision in abstract terms, but when one is looking at an actual manuscript with one negative review that could be due to a matter of taste, I think most authors would favor waiting a couple more weeks for a second opinion. Ex post, of course, if the later review also turns out negative and the decision is to reject, it would have been better to have made that decision earlier, but editors do not have the luxury of hindsight when only one review is in hand.

There are a couple of bright spots in our turnaround statistics. First, while many manuscripts take three months from submission to decision, very few (5.2\% to be exact) take four months or longer. Also, if the goal is to reach a final decision on a timely basis, I would submit that the turnaround time for each round comprises only a small part of the total. Time spent on the author's desk between rounds can be quite significant, as can the total number of rounds before a final decision is reached. Along that line, I think it is comforting that only nine of our 673 editorial decisions in fiscal 2010 were in the fourth round, and only one reached the fifth round (upon which it was accepted). We try to reach closure by the third round in the vast majority of cases. 


\section{SOME NOTES OF THANKS AND REMEMBRANCE}

\section{Notes of Thanks}

As I did last year, I close this report with several notes of thanks. First, I thank the person with whom most submitting authors and reviewers are quite familiar but have never met - Mary Capps. Mary works tirelessly to keep the "trains running on time," and she also is the source of those emails many reviewers have received with the capitalized word "REMINDER" at the beginning of the subject line. She is also fond of the one-line email "Have you had a chance to get to this yet?," followed by a smiley face icon. At a recent conference I attended, a faculty member observed to me, "Mary is quite persistent, isn't she?" He said it with a smile, and quickly followed up with a note of appreciation that someone cares so much about making the journal work as efficiently and effectively as possible, while remaining sensitive to personal circumstances that can arise from time to time. I agree.

Second, I thank my doctoral research assistant, Tracie Majors. Tracie has become "scary good" at researching new submissions to identify potential reviewers. She recognizes potential conflicts of interest not only from affiliations and coauthorships, but also from different perspectives. A typical Tracie comment would be, "Professor X clearly knows this area, but the author is taking issue with X's favored conclusion, so if you decide to go with X, you really need a second reviewer with a more independent perspective." Some might question the appropriateness of a doctoral student playing such an active role in proposing possible reviewers, but I view it as one of the wisest decisions I have made as senior editor. Unlike professors who develop different kinds of political baggage, Tracie's only exposure to a new submission is the manuscript itself and the literature to which it contributes. To be clear, Tracie only suggests a list 
of potential reviewers for my consideration (she does not make the decisions), but I have found her input to be invaluable.

Third, I thank my coeditors, Shannon Anderson, Harry Evans, Jim Hunton, Kathryn Kadous, Sanjay Kallapur, Ranjani Krishnan, Laureen Maines, Paul Newman, Tom Omer, Wayne Thomas, Mark Trombley, Beverly Walther, and Paul Zarowin. They never complain, even when they should, and their decisions are consistently of the highest ethical and professional caliber. For all their hard work, they get paid the grand sum of zero, so I am extremely grateful for their dedicated service. With over 500 new submissions per year, it would be impossible for any senior editor to do this job alone. Delegation to experts is essential, and I am comfortable placing complete trust in these 13 outstanding professionals.

Fourth, I thank TAR's Editorial Advisory and Review Board, as listed in the inside cover material of each issue. Like our coeditors, Editorial Board members get paid the whopping sum of zero for their service to $T A R$, and they put in a tremendous amount of hours completing six and sometimes more reviews per year. Six reviews per year might not seem too oppressive, but one has to keep in mind that our most demanded reviewers are probably also in high demand by other journals, and indeed, several of them serve on multiple journal editorial boards. In essence, the reward for gaining a reputation for doing timely, high-quality reviews is more review requests. We let no good deed go unpunished.

Fifth, I thank our ad hoc reviewers, the unsung heroes of any successful journal. Continuing a tradition I started last year, the Appendix lists all 453 ad hoc reviewers who completed one or more review reports between June 1, 2009 and May 31, 2010. I challenge the reader to find any research area (topical or methodological) that is not covered by at least a few 
names in this Appendix, so I hope that, in addition to thanking these individuals for their generosity, the Appendix also serves to signal TAR's diversity.

Sixth, I thank the exceptional professional staff of the American Accounting Association. I would start naming names, but surely I would inadvertently leave someone out who should be thanked, so I will just leave it at that. We send them accepted manuscripts, and they magically make a neat looking journal appear, including an invaluable copy editing service. (Authors: please do not read that as an excuse not to check your conditionally accepted manuscripts carefully before sending us the final revision.)

Seventh, I thank the University of Texas at Austin, including McCombs School of Business Dean Tom Gilligan and Department of Accounting Chair Urton Anderson, for supporting my service as senior editor of The Accounting Review. While most of my working hours since 2008 have been for an activity governed by the American Accounting Association, it is the University of Texas at Austin that pays my salary and makes this service possible. I still teach, which is my preference; I would never want to be out of the classroom entirely. But it is clear that the nature of my academic position has changed dramatically over the past two years (actually three, counting the extensive planning efforts an incoming senior editor must undertake before the term begins). I thank my employer for understanding and supporting me in this role and for recognizing the requisite tradeoffs.

Eighth, and perhaps most importantly, I thank my wife Paula and my daughters Karen, Nicole, and Sara. Last year at this time, my annual report mentioned the deck lighting I had been stalling for months while working virtually every weekend on TAR matters. I finally got the lighting installed (I think I could faintly hear my daughters in the background singing the Hallelujah chorus). This year's winner of the procrastination award goes to my 1992 Camaro, 
which sits in our garage gathering spider webs while I stall taking action on either fixing it or putting it out of its misery. We are all going camping next week - this time in Colorado. I will put a few TAR files in the pile with the camping gear, which I hope Paula "forgets" to bring along (meaning the files, not the gear). So add seven days to our average turnaround statistics for this month - I need the break, and family comes first when all is said and done. One sad note is that our loyal dog Midnight will not be anxiously awaiting our return this time, as she passed away last spring at the ripe old age of 11 . The nice thing about dogs is that their love is unconditional, no matter how badly you screw up. We miss her greatly.

\section{Remembrances}

While not part of the annual report per se, I will exercise my editorial prerogative to offer a few comments on two leaders in our profession who passed away this year - John Dickhaut and Anthony Hopwood. Both exhibited inspirational leadership in daring to challenge the received wisdom in accounting research, and both were true scholars in every sense of that word.

My most vivid early recollection of John Dickhaut was when I was a doctoral student at the University of Florida in the mid-1980s and John was an invited workshop guest. I distinctly remember an intense discussion of backward induction and multiperiod reputations with John while in the men's underwear department of the local J.C. Penney's, as John had asked me to take him there during the lunch hour because he had forgotten to pack any clothes for his two-day visit. This was vintage John Dickhaut - a man who could forget trivial things like packing a suitcase, but who at the same time was absolutely brilliant in his understanding of the interface between human behavior and accounting. About ten years later, I gave John Dickhaut most of the credit for making sure the two words "and experimental" were included in the "Aims and Scope" statement for Review of Accounting Studies, a new journal for which John was one of 
the founding editors. For The Accounting Review, I take special pride in the fact that we had the privilege of publishing two of John's final scholarly works - both in the same issue (Dickhaut 2009; Dickhaut and Xin 2009). Those who value diversity and quality in accounting scholarship should read both articles. Finally, on a somewhat sad but telling note, the reader will see John's name in the Appendix of ad hoc reviewers this year, as he turned in a review of a first-round submission just the week before he passed away, using voice-recognition software to help compose his thoughts. He recommended revision.

I did not have as much personal knowledge of Anthony Hopwood, but I greatly appreciate his influence on the discipline, not only as editor of Accounting, Organizations and Society, but also as a persistent champion for diversity in accounting scholarship. I wonder how he might react to Table 3 in this report. In the commentary based on his 2006 AAA Presidential Scholar Lecture, Professor Hopwood issued a special challenge for The Accounting Review as the Association's flagship journal, urging that "every effort be made to encourage The Accounting Review to embrace the new, the innovative, what accounting research might be in the process of becoming, and new interdisciplinary perspectives, ... in a way that provides both a catalyst and a model for other journals of influence" (Hopwood 2007, 1373). The challenge is profound. I am trying, and it is my heartfelt conviction that TAR senior editors and coeditors past, present, and future would join me in agreeing with Professor Hopwood's challenge. But innovation in any discipline is a team sport. We need the help of the scholarly community in accounting to make it happen. 


\section{REFERENCES}

Blank, R. M. 1991. The effects of double-blind versus single-blind reviewing: Experimental evidence from The American Economic Review. The American Economic Review 81 (December): 1041-1067.

Coyne, J. G., S. L. Summers, B. Williams, and D. A. Wood. 2010. Accounting program research rankings by topical area and methodology. Issues in Accounting Education: forthcoming.

Dickhaut, J. 2009. The brain as the original accounting institution. The Accounting Review 84 (November): 1703-1712. , and B. Xin. 2009. Market efficiencies and drift: A computational model. The Accounting Review 84 (November): 1805-1831.

Gilliland, S. W., and J. M. Cortina. 1997. Reviewer and editor decision making in the journal review process. Personnel Psychology 50 (Summer): 427-452.

Hopwood, A. G. 2007. Whither accounting research? The Accounting Review 82 (October): 1365-1374.

Kachelmeier, S. J. 2004. Reviewing the review process. The Journal of the American Taxation Association 26 (Supplement): 143-154.

. 2009. Annual report and editorial commentary for The Accounting Review. The Accounting Review 84 (November): 2047-2075.

Lynch, J. G., Jr. 1998. Reviewing. Advances in Consumer Research 25: 1-6.

Merchant, K. A. 2010. Paradigms in accounting research: A view from North America. Management Accounting Research 21 (June): 116-120.

Tuttle, B., and J. Dillard. 2007. Beyond competition: Institutional isomorphism in U.S. accounting research. Accounting Horizons 21 (December): 387-409. 


\section{Chart 1}

Histogram of Editorial Rounds and Outcomes

Journal Year Ending May 31, 2010

Panel A: First-Round Outcomes (New Submissions)

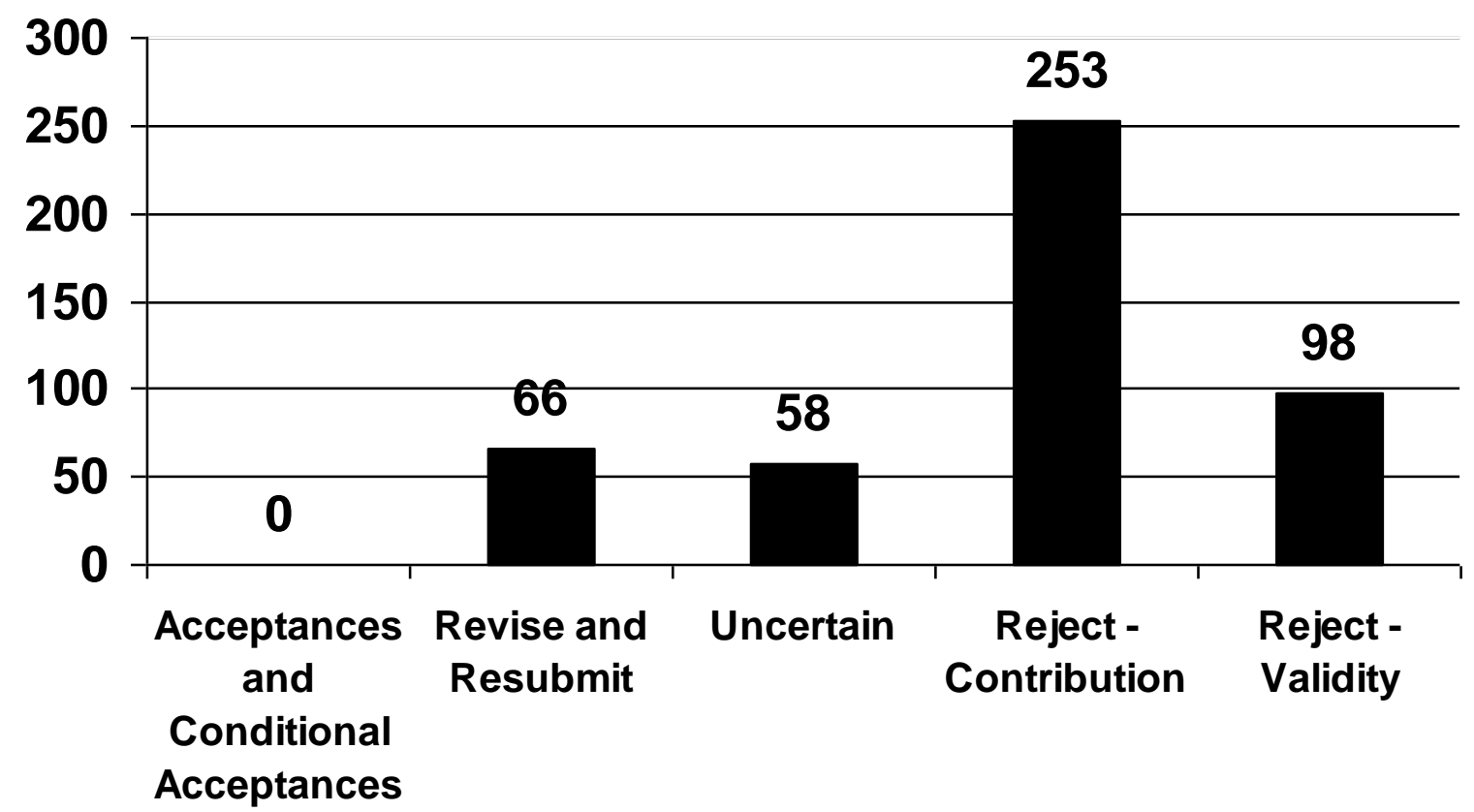

Panel B: Second-Round Outcomes (First Revisions)

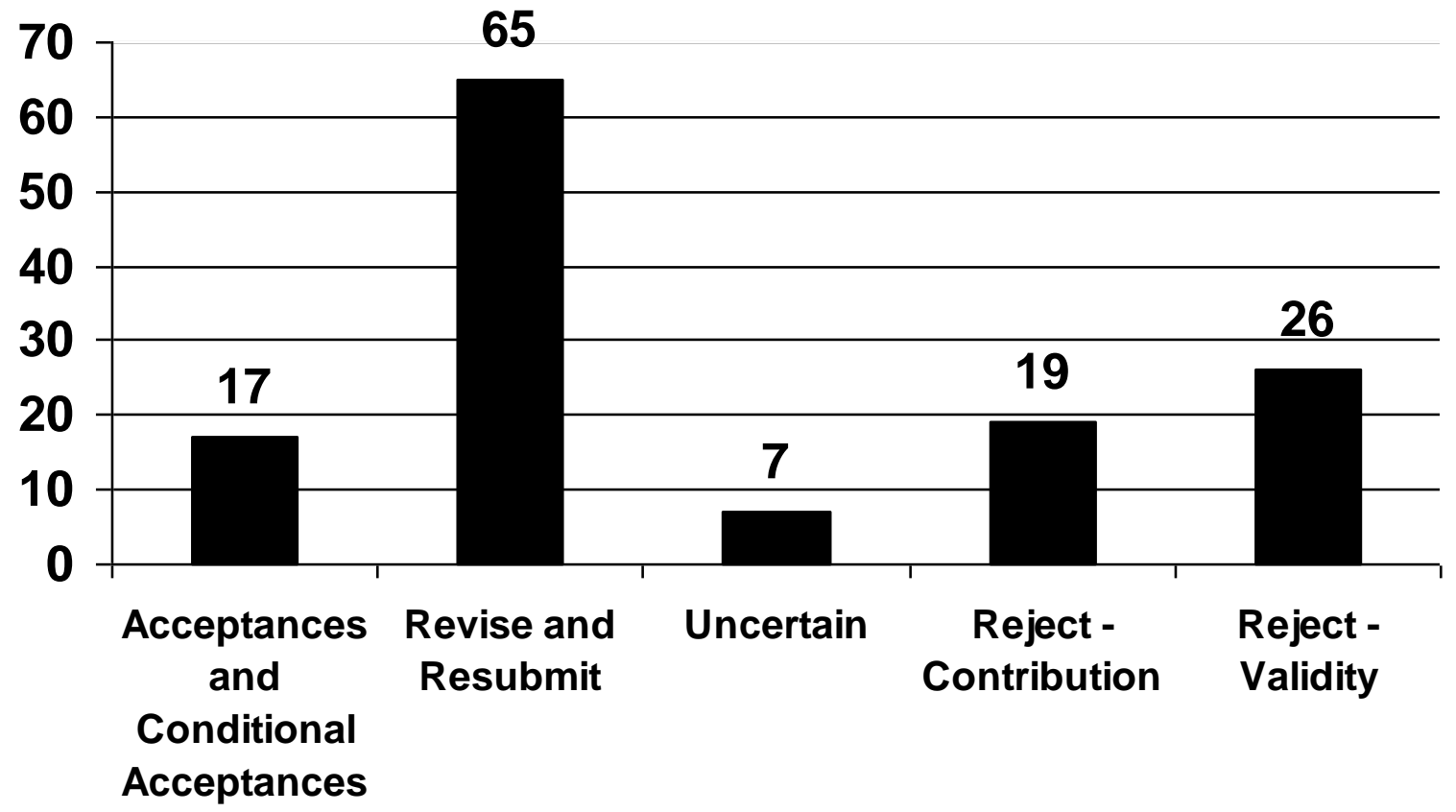


Chart 1, Histogram of Editorial Rounds and Outcomes for the Journal Year Ending May 31, 2010, continued

Panel C: Third- and Fourth-Round Outcomes (Second and Third Revisions)

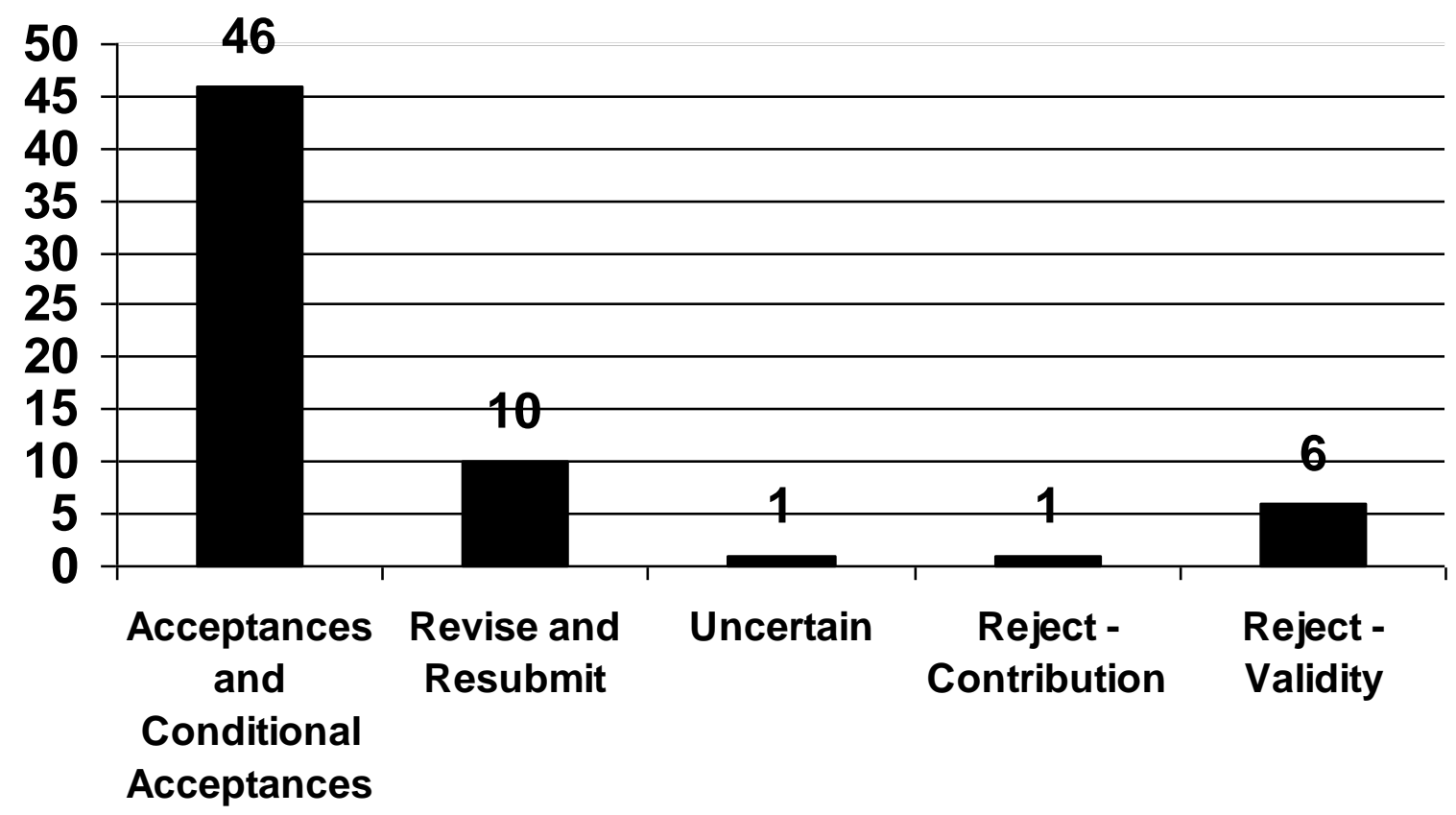




\section{Table 1}

Annual Activity Summary

Panel A: Annual Activity Summary by Journal Year

\begin{tabular}{ccccccc} 
Manuscripts & \multicolumn{9}{c}{$\begin{array}{c}\text { Manuscripts } \\
\text { Available } \\
\text { fournal } \\
\text { Year }\end{array}$} & $\begin{array}{c}\text { in Process at } \\
\text { Beginning of }\end{array}$ & $\begin{array}{c}\text { New } \\
\text { Submissions } \\
\text { Received }\end{array}$ & $\begin{array}{c}\text { Resubmissions } \\
\text { Received }\end{array}$ & $\begin{array}{c}\text { Evaluation } \\
\text { (d) }\end{array}$ & $\begin{array}{c}\text { Decision } \\
\text { Letters } \\
\text { Sent } \\
\text { Ending }\end{array}$ & $\begin{array}{c}\text { Year } \\
\text { May 31, }\end{array}$ & $\begin{array}{c}\text { Manuscripts } \\
\text { (a) }\end{array}$ & (b) $)$ & $\begin{array}{c}\text { in Process at } \\
\text { End of Year } \\
(\mathbf{f})=(\mathbf{d})-(\mathbf{e})\end{array}$ \\
\hline 2009 & 133 & 557 & 163 & 853 & 719 & 134 \\
2010 & 134 & 502 & 212 & 848 & 673 & 175
\end{tabular}

Explanations of columns:

(a) Manuscripts in process include all new submissions and revisions pending decision (generally awaiting review), but exclude manuscripts awaiting revision from authors.

(b) New manuscripts, excluding resubmissions of revised manuscripts.

(c) Resubmissions of invited revisions.

(d) Summation of columns (a), (b), and (c).

(e) Completed decision letters, including subsequent decisions for manuscripts previously evaluated as a "revise and resubmit" decision within the same fiscal year.

(f) Manuscripts awaiting review and/or editorial decision as of the end of the journal's fiscal year.

\section{Panel B: New Submissions by Calendar Year}

\begin{tabular}{|c|c|}
\hline Calendar Year & $\begin{array}{c}\text { New } \\
\text { Submissions }\end{array}$ \\
\hline 1998 & 196 \\
\hline 1999 & 239 \\
\hline 2000 & 260 \\
\hline 2001 & 328 \\
\hline 2002 & 324 \\
\hline 2003 & 327 \\
\hline 2004 & 307 \\
\hline 2005 & 389 \\
\hline 2006 & 413 \\
\hline 2007 & 443 \\
\hline 2008 & 482 \\
\hline 2009 & 508 \\
\hline
\end{tabular}


Table 2

Annual Outcome Summary

Panel A: Outcomes by Fiscal Year

\begin{tabular}{|c|c|c|c|c|c|c|}
\hline $\begin{array}{c}\text { Journal } \\
\text { Year } \\
\text { Ending } \\
\text { May 31, }\end{array}$ & $\begin{array}{c}\text { Decision } \\
\text { Letters } \\
\text { Sent } \\
\text { (a) } \\
\end{array}$ & $\begin{array}{l}\text { Rejections } \\
\text { (b) }\end{array}$ & $\begin{array}{c}\text { Revise and } \\
\text { "Uncertain" } \\
\text { Decisions } \\
\text { (c) }\end{array}$ & $\begin{array}{c}\text { Acceptances } \\
\text { and } \\
\text { Conditional } \\
\text { Acceptances } \\
\text { (d) } \\
\end{array}$ & $\begin{array}{c}\text { Acceptance } \\
\text { Rate 1: } \\
(\mathbf{e}) \\
=(\mathbf{d}) /[(\mathbf{b})+(\mathbf{d})]\end{array}$ & $\begin{array}{c}\text { Acceptance } \\
\text { Rate 2: } \\
(\mathbf{f})=(\mathbf{d}) /(\mathbf{a})\end{array}$ \\
\hline 2009 & 719 & 408 & 230 & 81 & $16.6 \%$ & $11.3 \%$ \\
\hline 2010 & 673 & 403 & 207 & 63 & $13.5 \%$ & $9.4 \%$ \\
\hline
\end{tabular}

Explanations of columns:

(a) This column is the same as column (e) of Table 1, Panel A, reflecting all decision letters sent during the fiscal year, including decisions on manuscripts that had already been evaluated previously within the same fiscal year (with invitation to revise and resubmit). Thus, the number of unique manuscript files processed is somewhat lower than the number of decision letters sent.

(b) Chart 1 separates the total rejections into manuscripts rejected due primarily to insufficient contribution and manuscripts rejected due primarily to a perceived threat to the validity of the reported claims.

(c) Chart 1 separates this column into decisions logged as standard "revise-and-resubmit" outcomes and decisions logged as "uncertain" outcomes that allow but do not necessarily encourage resubmission.

(d) Total acceptances and conditional acceptances include manuscripts published and forthcoming in The Accounting Review. Thus, the total acceptances during a year do not represent the actual number of articles published during that year. Acceptance totals include only those files accepted from the normal review process, and exclude invited commentaries from AAA Presidential Scholar Lectures and from occasional research forums.

Panel B: Final Outcome Resolution for All New Submissions

\begin{tabular}{|c|c|c|c|c|c|c|}
\hline $\begin{array}{l}\text { Journal } \\
\text { Year } \\
\text { Ending } \\
\text { May 31, }\end{array}$ & $\begin{array}{c}\text { New } \\
\text { Submissions } \\
\text { Received } \\
\text { (a) }\end{array}$ & $\begin{array}{c}\text { Acceptances } \\
\text { through } \\
\text { May 31, } \\
2010 \\
\text { (b) }\end{array}$ & $\begin{array}{l}\text { Rejections } \\
\text { through } \\
\text { May 31, } \\
2010 \\
\text { (c) }\end{array}$ & $\begin{array}{l}\text { Files Pending } \\
\text { Further } \\
\text { Revision as of } \\
\text { May 31, 2010 } \\
\text { (d) }\end{array}$ & $\begin{array}{c}\text { Lower } \\
\text { Bound on } \\
\text { Acceptance } \\
\text { Rate: } \\
(\mathbf{e})=(\mathbf{b}) /(\mathbf{a})\end{array}$ & $\begin{array}{l}\text { Upper Bound } \\
\text { on Acceptance } \\
\text { Rate: } \\
(\mathbf{f}) \\
=[(\mathbf{b})+(\mathbf{d})] /(\mathbf{a})\end{array}$ \\
\hline 2009 & 557 & 45 & 442 & 70 & $8.1 \%$ & $20.6 \%$ \\
\hline
\end{tabular}


Table 3

Submissions and Acceptances by Subject Area and Research Method

Journal Year Ending May 31, 2010

\section{Panel A: Submissions and Acceptances by Subject Area}

\begin{tabular}{|c|c|c|c|c|}
\hline $\begin{array}{c}\text { Primary Subject } \\
\text { Area } \\
\text { (a) }\end{array}$ & $\begin{array}{l}\text { Submissions } \\
\text { Representing } \\
\text { Unique } \\
\text { Manuscript } \\
\text { Files with } \\
\text { Decisions } \\
\text { (b) }\end{array}$ & $\begin{array}{l}\text { Percentage of } \\
\text { Total } \\
\text { Submissions } \\
\text { (c) }\end{array}$ & $\begin{array}{l}\text { Acceptances } \\
\text { and } \\
\text { Conditional } \\
\text { Acceptances } \\
\text { (d) }\end{array}$ & $\begin{array}{c}\text { Percentage } \\
\text { of Total } \\
\text { Acceptances } \\
\text { (e) }\end{array}$ \\
\hline Auditing & 110 & $17.9 \%$ & 13 & $20.6 \%$ \\
\hline Financial & 327 & $53.2 \%$ & 31 & $49.2 \%$ \\
\hline Governmental and & & & & \\
\hline Not-for-Profit & 7 & $1.1 \%$ & 0 & $0.0 \%$ \\
\hline International & 37 & $6.0 \%$ & 2 & $3.2 \%$ \\
\hline Managerial & 84 & $13.7 \%$ & 8 & $12.7 \%$ \\
\hline Systems & 12 & $2.0 \%$ & 2 & $3.2 \%$ \\
\hline Taxation & 34 & $5.5 \%$ & 7 & $11.1 \%$ \\
\hline Other & 4 & $0.6 \%$ & 0 & $0.0 \%$ \\
\hline Total & 615 & $100.0 \%$ & 63 & $100.0 \%$ \\
\hline
\end{tabular}

Explanations of columns:

(a) Subject (Panel A) and method (Panel B) categories are as directed by the AAA Publications Committee. Manuscripts that overlapped categories were assigned to the category best capturing the study's primary objective, as judged by the Senior Editor.

(b) This column reflects the 615 unique manuscript files obtained by taking the 673 editorial decisions during the fiscal year as tallied in Table 1, Panel A and subtracting the 58 reviseand-resubmit decisions on manuscripts for which a subsequent decision was logged within the same fiscal year on the same file, thereby avoiding double counting of categories for the same manuscript files.

(c) This column represents the entry in Column (b) divided by 615 unique manuscript files.

(d) This column reflects the 63 acceptance and conditional acceptance decisions reached on the 615 unique manuscript files in Column (b).

(e) This column represents the entry in Column (d) divided by 63 acceptances and conditional acceptances. 
Table 3, Submissions and Acceptances by Subject Area and Method, Journal Year Ending May 31, 2010, continued

Panel B: Submissions and Acceptances by Method

\begin{tabular}{lcccc} 
& $\begin{array}{c}\text { Submissions } \\
\text { Representing } \\
\text { Unique } \\
\text { Manuscript } \\
\text { Files with } \\
\text { Decisions } \\
\text { Primary Research } \\
\begin{array}{c}\text { Method } \\
\text { (a) }\end{array}\end{array}$ & $\begin{array}{c}\text { Percentage of } \\
\text { Total } \\
\text { Submissions } \\
\text { (c) }\end{array}$ & $\begin{array}{c}\text { Acceptances } \\
\text { and } \\
\text { Conditional } \\
\text { Acceptances } \\
\text { (d) }\end{array}$ & $\begin{array}{c}\text { Percentage } \\
\text { of Total } \\
\text { Acceptances } \\
\text { (e) }\end{array}$ \\
\hline Analytical & 42 & $6.8 \%$ & 7 & $11.1 \%$ \\
Empirical-Archival & 457 & $74.3 \%$ & 40 & $63.5 \%$ \\
Experimental & 86 & $14.0 \%$ & 13 & $20.6 \%$ \\
Field and Case Study & 8 & $1.3 \%$ & 2 & $3.2 \%$ \\
Survey & 15 & $2.4 \%$ & 1 & $1.6 \%$ \\
Other & 7 & $1.1 \%$ & 0 & $0.0 \%$ \\
\hline Total & 615 & $100.0 \%$ & 63 & $100.0 \%$
\end{tabular}

Explanations of columns:

See explanations for Panel A, above.

Panel C: Submissions and (Acceptances) by Subject Area Crossed with Method

\begin{tabular}{|l|c|c|c|c|c|c|}
\hline $\begin{array}{c}\text { Subject and } \\
\text { Method }\end{array}$ & Auditing & Financial & Managerial & Taxation & $\begin{array}{c}\text { All Other } \\
\text { Subjects }\end{array}$ & \begin{tabular}{c} 
Total \\
\hline Analytical
\end{tabular} \\
& $7(1)$ & $20(3)$ & $12(2)$ & $1(1)$ & $2(0)$ & $42(7)$ \\
& $1 \%(2 \%)$ & $3 \%(5 \%)$ & $2 \%(3 \%)$ & $<1 \%(2 \%)$ & $<1 \%(0 \%)$ & $7 \%(11 \%)$ \\
\hline Empirical- & $70(5)$ & $276(23)$ & $36(3)$ & $29(6)$ & $46(3)$ & $457(40)$ \\
Archival & $11 \%(8 \%)$ & $45 \%(37 \%)$ & $6 \%(5 \%)$ & $5 \%(10 \%)$ & $7 \%(5 \%)$ & $74 \%(63 \%)$ \\
\hline Experimental & $28(6)$ & $25(5)$ & $22(2)$ & $2(0)$ & $9(0)$ & $86(13)$ \\
& $5 \%(10 \%)$ & $4 \%(8 \%)$ & $4 \%(3 \%)$ & $<1 \%(0 \%)$ & $1 \%(0 \%)$ & $14 \%(21 \%)$ \\
\hline All Other & $5(1)$ & $6(0)$ & $14(1)$ & $2(0)$ & $3(1)$ & $30(3)$ \\
Methods & $1 \%(2 \%)$ & $1 \%(0 \%)$ & $2 \%(2 \%)$ & $<1 \%(0 \%)$ & $<1 \%(2 \%)$ & $5 \%(5 \%)$ \\
\hline Total & $110(13)$ & $327(31)$ & $84(8)$ & $34(7)$ & $60(4)$ & $615(63)$ \\
& $18 \%(21 \%)$ & $53 \%(49 \%)$ & $14 \%(13 \%)$ & $6 \%(11 \%)$ & $10 \%(6 \%)$ & $100 \%$ \\
\hline
\end{tabular}

Note:

Cell entries reflect submissions first, then acceptances (in parentheses). The top row for each cell indicates raw counts. The bottom row computes percentages of the 615 total unique submissions and 63 total acceptances, respectively, rounded to the nearest whole percentage to enable the table to fit in the available space. 
Table 4

Author Affiliation

Panel A: Universities and Other Institutions Represented in Vols. 84 (2009) and 85 (2010)

\begin{tabular}{|c|c|c|}
\hline $\begin{array}{r}\text { Author Affiliation } \\
\end{array}$ & $\begin{array}{c}\text { Current-Year } \\
\text { Number of } \\
\text { Published } \\
\text { Articles } \\
\text { (Vol. 85, 2010) } \\
\end{array}$ & $\begin{array}{c}\text { Two-Year } \\
\text { Cumulative } \\
\text { Number of } \\
\text { Published Articles } \\
\text { (2009 and 2010) } \\
\end{array}$ \\
\hline The University of Texas at Austin & 5.58 & 6.08 \\
\hline University of Pennsylvania & 2.25 & 4.67 \\
\hline Stanford University & 2.17 & 4.17 \\
\hline Michigan State University & 1.75 & 3.92 \\
\hline Harvard University & 1.58 & 3.75 \\
\hline Dartmouth College & 3.42 & 3.42 \\
\hline University of Illinois at Urbana-Champaign & 1.50 & 3.17 \\
\hline The University of Georgia & 2.92 & 2.92 \\
\hline The University of Iowa & 0.50 & 2.75 \\
\hline University of Michigan & 1.33 & 2.67 \\
\hline University of Pittsburgh & 1.00 & 2.67 \\
\hline University of Toronto & 0.83 & 2.58 \\
\hline Indiana University & 1.00 & 2.50 \\
\hline The University of Chicago & 1.50 & 2.33 \\
\hline The George Washington University & 1.00 & 2.33 \\
\hline Florida International University & 1.25 & 2.08 \\
\hline The Pennsylvania State University & 1.33 & 2.00 \\
\hline The University of New South Wales & 0.00 & 1.83 \\
\hline University of Missouri - Columbia & 1.00 & 1.83 \\
\hline Nanyang Technological University & 1.50 & 1.83 \\
\hline Hong Kong Polytechnic University & 1.67 & 1.79 \\
\hline The University of Oklahoma & 1.17 & 1.75 \\
\hline The University of Texas at Dallas & 0.58 & 1.75 \\
\hline University of California, Los Angeles & 1.33 & 1.67 \\
\hline Emory University & 1.67 & 1.67 \\
\hline The University of North Carolina at Chapel Hill & 1.33 & 1.67 \\
\hline Texas A\&M University & 0.33 & 1.67 \\
\hline The University of Utah & 0.83 & 1.67 \\
\hline University of Wisconsin - Madison & 0.25 & 1.58 \\
\hline University of California, Berkeley & 0.00 & 1.50 \\
\hline Singapore Management University & 0.00 & 1.50 \\
\hline University of Minnesota & 0.00 & 1.25 \\
\hline University of Alberta & 1.17 & 1.17 \\
\hline Brigham Young University & 0.00 & 1.17 \\
\hline
\end{tabular}

Panel A continued on next page. 
Table 4, Author Affiliation, continued

$\underline{\text { Panel A, continued }}$

\begin{tabular}{|c|c|c|}
\hline $\begin{array}{c}\text { Author Affiliation } \\
\end{array}$ & $\begin{array}{c}\text { Current-Year } \\
\text { Number of } \\
\text { Published } \\
\text { Articles } \\
(\text { Vol. 85, 2010) } \\
\end{array}$ & $\begin{array}{c}\text { Two-Year } \\
\text { Cumulative } \\
\text { Number of } \\
\text { Published Articles } \\
(2009 \text { and 2010) } \\
\end{array}$ \\
\hline Hong Kong University of Science and Technology & 0.33 & 1.17 \\
\hline University of Southern California & 0.00 & 1.17 \\
\hline University of Virginia & 0.50 & 1.17 \\
\hline Aarhus University & 1.00 & 1.00 \\
\hline University of Arkansas & 1.00 & 1.00 \\
\hline Universidad Carlos III de Madrid & 0.00 & 1.00 \\
\hline Georgia Institute of Technology & 0.00 & 1.00 \\
\hline Humboldt University - Berlin & 0.00 & 1.00 \\
\hline Iowa State University & 0.00 & 1.00 \\
\hline McGill University & 0.00 & 1.00 \\
\hline University of Melbourne & 0.00 & 1.00 \\
\hline Miami University (Ohio) & 1.00 & 1.00 \\
\hline National University of Singapore & 1.00 & 1.00 \\
\hline University of New Hampshire & 1.00 & 1.00 \\
\hline Purdue University & 1.00 & 1.00 \\
\hline University of Rochester & 0.00 & 1.00 \\
\hline Saint Louis University & 1.00 & 1.00 \\
\hline Santa Clara University & 1.00 & 1.00 \\
\hline Southern Methodist University & 1.00 & 1.00 \\
\hline Tel Aviv University & 1.00 & 1.00 \\
\hline Washington University at St. Louis & 0.00 & 1.00 \\
\hline University of Alabama & 0.83 & 0.83 \\
\hline Cornell University & 0.33 & 0.83 \\
\hline University of Houston & 0.33 & 0.83 \\
\hline Maastricht University & 0.00 & 0.83 \\
\hline Massachusetts Institute of Technology & 0.67 & 0.83 \\
\hline The Ohio State University & 0.83 & 0.83 \\
\hline University of Oregon & 0.83 & 0.83 \\
\hline Seoul National University & 0.58 & 0.83 \\
\hline Bentley University & 0.25 & 0.75 \\
\hline University of California, Irvine & 0.00 & 0.75 \\
\hline Erasmus University & 0.33 & 0.75 \\
\hline Duke University & 0.00 & 0.67 \\
\hline Rice University & 0.00 & 0.67 \\
\hline University of South Florida & 0.00 & 0.67 \\
\hline
\end{tabular}

Panel A continued on next page. 
Table 4, Author Affiliation, continued

$\underline{\text { Panel A, continued }}$

\begin{tabular}{lcc}
\multicolumn{1}{c}{ Author Affiliation } & $\begin{array}{c}\text { Current-Year } \\
\text { Number of } \\
\text { Published } \\
\text { Articles } \\
\text { (Vol. 85, 2010) }\end{array}$ & $\begin{array}{c}\text { Two-Year } \\
\text { Cumulative } \\
\text { Number of } \\
\text { Published Articles } \\
\text { (2009 and 2010) }\end{array}$ \\
\hline University of Washington & 0.67 & 0.67 \\
Concordia University & 0.50 & 0.63 \\
University of British Columbia & 0.33 & 0.58 \\
University of Connecticut & 0.00 & 0.58 \\
University of Notre Dame & 0.00 & 0.58 \\
University of South Carolina & 0.58 & 0.58 \\
University of Amsterdam & 0.00 & 0.50 \\
Boston University & 0.50 & 0.50 \\
Columbia University & 0.00 & 0.50 \\
University of Florida & 0.00 & 0.50 \\
Goethe University & 0.00 & 0.50 \\
Korea University & 0.50 & 0.50 \\
University of Miami & 0.50 & 0.50 \\
Norwegian School of Management & 0.50 & 0.50 \\
Utah State University & 0.00 & 0.50 \\
Washington State University & 0.00 & 0.50 \\
University of Waterloo & 0.00 & 0.50 \\
University of Antwerp & 0.00 & 0.33 \\
University of Arizona & 0.33 & 0.33 \\
Arizona State University & 0.00 & 0.33 \\
University of Auckland & 0.00 & 0.33 \\
University of California, Davis & 0.00 & 0.33 \\
University of California, San Diego & 0.00 & 0.33 \\
Carnegie Mellon University & 0.33 & 0.33 \\
China Europe International Business School & 0.33 & 0.33 \\
Colorado State University & 0.00 & 0.33 \\
Drexel University & 0.33 & 0.33 \\
George Mason University & 0.33 & 0.33 \\
Gradient Analytics, Inc. & 0.33 & 0.33 \\
HEC Paris & 0.00 & 0.33 \\
Inha University & 0.33 & 0.33 \\
Lehigh University & 0.33 & 0.33 \\
University of Massachusetts, Dartmouth & 0.33 & 0.33 \\
McMaster University & 0.33 & 0.33 \\
Meijo University & 0.00 & 0.33 \\
& & \\
& &
\end{tabular}

Panel A continued on next page. 
Table 4, Author Affiliation, continued

$\underline{\text { Panel A, continued }}$

\begin{tabular}{|c|c|c|}
\hline Author Affiliation & $\begin{array}{c}\text { Current-Year } \\
\text { Number of } \\
\text { Published } \\
\text { Articles } \\
\text { (Vol. 85, 2010) }\end{array}$ & $\begin{array}{c}\text { Two-Year } \\
\text { Cumulative } \\
\text { Number of } \\
\text { Published Articles } \\
\text { (2009 and 2010) }\end{array}$ \\
\hline University of Nevada, Las Vegas & 0.00 & 0.33 \\
\hline New York University & 0.00 & 0.33 \\
\hline North Carolina State University & 0.33 & 0.33 \\
\hline Northeastern University & 0.00 & 0.33 \\
\hline Northwestern University & 0.33 & 0.33 \\
\hline Osaka University of Economics & 0.00 & 0.33 \\
\hline Sungkyunkwan University & 0.33 & 0.33 \\
\hline Syracuse University & 0.00 & 0.33 \\
\hline The University of Tennessee & 0.00 & 0.33 \\
\hline Virginia Commonwealth University & 0.33 & 0.33 \\
\hline Virginia Polytechnic Institute and State University & 0.33 & 0.33 \\
\hline Wichita State University & 0.33 & 0.33 \\
\hline Ball State University & 0.00 & 0.25 \\
\hline Chapman University & 0.00 & 0.25 \\
\hline University of Hong Kong & 0.00 & 0.25 \\
\hline Illinois State University & 0.25 & 0.25 \\
\hline Indian School of Business & 0.00 & 0.25 \\
\hline Kent State University & 0.00 & 0.25 \\
\hline University of Massachusetts, Amherst & 0.25 & 0.25 \\
\hline Mississippi State University & 0.25 & 0.25 \\
\hline Oklahoma State University & 0.25 & 0.25 \\
\hline Tilburg University & 0.25 & 0.25 \\
\hline Barclays Global Investors & 0.00 & 0.17 \\
\hline Copenhagen Business School & 0.00 & 0.17 \\
\hline Interdisciplinary Center - Herzliya & 0.00 & 0.17 \\
\hline University of Southern Maine & 0.00 & 0.17 \\
\hline
\end{tabular}

Panel A reports author affiliations for all articles published in Volume 84 (calendar 2009) and Volume 85 (calendar 2010) of The Accounting Review, excluding invited commentaries. For articles written by $\mathrm{k}$ coauthors, the table allocates $1 / \mathrm{k}$ of an article to each coauthor's affiliation. For authors indicating two affiliations, that author's $1 / \mathrm{k}$ share is allocated equally to both affiliations. 
Panel B: U.S. and non-U.S. Affiliations Represented in Vols. 84 (2009) and 85 (2010)

Journal Year Ending

May 31, 2010

\begin{tabular}{|c|c|c|c|c|}
\hline & \multicolumn{2}{|c|}{ May 31, 2010 } & \multicolumn{2}{|c|}{ May 31, 2010 } \\
\hline & $\begin{array}{c}\text { Number } \\
\text { (Percentage) of } \\
\text { Submissions } \\
\text { Representing } \\
\text { Unique } \\
\text { Manuscript } \\
\text { Files with } \\
\text { Decisions } \\
\end{array}$ & $\begin{array}{c}\text { Number } \\
\text { (Percentage) of } \\
\text { Acceptances } \\
\end{array}$ & $\begin{array}{c}\text { Number } \\
\text { (Percentage) of } \\
\text { Submissions } \\
\text { Representing } \\
\text { Unique } \\
\text { Manuscript } \\
\text { Files with } \\
\text { Decisions } \\
\end{array}$ & $\begin{array}{c}\text { Number } \\
\text { (Percentage) of } \\
\text { Acceptances } \\
\end{array}$ \\
\hline $\begin{array}{l}\text { U.S. } \\
\text { Institutions } \\
\text { Non-U.S. }\end{array}$ & $448.93(73.0 \%)$ & $50.34(79.9 \%)$ & $825.84(73.3 \%)$ & $115.50(80.2 \%)$ \\
\hline Institutions & $166.07(27.0 \%)$ & $12.66(20.1 \%)$ & $301.16(26.7 \%)$ & $28.50(19.8 \%)$ \\
\hline
\end{tabular}

Cumulative from June 1, 2008 to

May 31, 2010

Panel B reports data for authors' affiliations, allocating $1 / \mathrm{k}$ of each manuscript to each of $\mathrm{k}$ coauthors. Submissions data for the journal year ending May 31, 2010 reflect the 615 unique files for which decisions were reached in fiscal 2010, excluding files for which two or more decisions were reached within the year due to invitations to revise and resubmit. Cumulative submissions data from June 1, 2008 to May 31, 2010 (i.e., two journal years) reflect the 1,127 unique manuscript files for which a decision was logged in either year, but not double counting files for which a decision was reached in both years (due to revision). Acceptance data reflect all acceptances and conditional acceptances reached in the journal years ending May 31, 2009 and May 31, 2010, including some acceptances that are scheduled for publication in early 2011. Hence, the acceptance data in this panel will not equal the total acceptances in Panel A, as Panel A only reflects actual articles published in calendar 2009 and calendar 2010, excluding forthcoming articles accepted for future publication. 
Table 5

Processing Time from Date of Submission to Date of Sending the Decision Journal Year Ending May 31, 2010

\begin{tabular}{|l|c|c|c|c|}
\hline Processing Time & $\begin{array}{c}\text { Number of } \\
\text { Manuscripts }\end{array}$ & Percentage & $\begin{array}{c}\text { Cumulative } \\
\text { Number of } \\
\text { Manuscripts }\end{array}$ & $\begin{array}{c}\text { Cumulative } \\
\text { Percentage }\end{array}$ \\
\hline$\leq 30$ days & 36 & $5.3 \%$ & 36 & $5.3 \%$ \\
\hline $31-60$ days & 72 & $10.7 \%$ & 108 & $16.0 \%$ \\
\hline $61-90$ days & 227 & $33.7 \%$ & 335 & $49.8 \%$ \\
\hline $91-120$ days & 303 & $45.0 \%$ & 638 & $94.8 \%$ \\
\hline$\geq 121$ days & 35 & $5.2 \%$ & 673 & $100.0 \%$ \\
\hline
\end{tabular}

Mean processing time: 86 days.

Median processing time: 91 days. 


\section{Appendix \\ TAR Ad Hoc Reviewers, June 1, 2009 - May 31, 2010}

Note: This table lists all ad hoc reviewers who submitted at least one review report between June 1, 2009 and May 31, 2010. It does not include the 129 members of the Editorial Advisory and Review Board, as those names are listed separately in the inside cover material of each issue. Ad hoc reviewers whose reports were submitted after May 31, 2010 will be included in next year's report.

Lawrence Abbott, University of Wisconsin-Milwaukee

A. Rashad Abdel-khalik, University of Illinois at Urbana-Champaign

Margaret Abernethy, University of Melbourne

David Aboody, University of California, Los Angeles

Andrew Acito, The University of Iowa

Christopher Agoglia, University of Massachusetts, Amherst

Kris Allee, Michigan State University

Michael Alles, Rutgers University

Urton Anderson, The University of Texas at Austin

Christopher Armstrong, University of Pennsylvania

Sharad Asthana, The University of Texas at San Antonio

Brad Badertscher, University of Notre Dame

Kee-Hong Bae, York University

Mark Bagnoli, Purdue University

Bok Baik, Seoul National University

Wendy Bailey, University of South Carolina

Steven Balsam, Temple University

Michael Bamber, The University of Georgia

Ran Barniv, Kent State University

Mary Barth, Stanford University

Jan Barton, Emory University

Eli Bartov, New York University

Mark Beasley, North Carolina State University

Paul Beck, University of Illinois at Urbana-Champaign

Joy Begley, University of British Columbia

Bruce Behn, University of Tennessee

Messod Beneish, Indiana University

Daniel Bens, University of Arizona

Jeremy Bertomeu, Northwestern University

Anne Beyer, Stanford University

Sreedhar Bharath, Arizona State University

Neil Bhattacharya, Southern Methodist University

Sanjeev Bhojraj, Cornell University

Gary Biddle, The University of Hong Kong

Bruce Billings, Florida State University

Continued 
Mary Brooke Billings, New York University

Erv Black, Brigham Young University

Jeff Boone, The University of Texas at San Antonio

Jan Bouwens, Tilburg University

Robert Bowen, University of Washington

Kendall Bowlin, University of Mississippi

Joe Brazel, North Carolina State University

Francois Brochet, Harvard University

Jason Brown, Indiana University

Jennifer Brown, Arizona State University

Jörg Budde, University of Bonn

David Burgstahler, University of Washington

Jeffrey Burks, University of Notre Dame

Robert Bushman, University of North Carolina at Chapel Hill

Brian Cadman, University of Utah

Steven Cahan, University of Auckland

Andrew Call, The University of Georgia

Dennis Campbell, Harvard University

Eddy Cardinaels, Tilburg University

Peter Carey, Monash University

Tina Carpenter, The University of Georgia

Elizabeth Carson, The University of New South Wales

Judson Caskey, University of California, Los Angeles

Gavin Cassar, University of Pennsylvania

Jeffrey Casterella, Colorado State University

Marcus Caylor, University of South Carolina

Sandra Chamberlain, University of British Columbia

Dennis Chambers, Kennesaw State University

Chih-Ying Chen, Singapore Management University

Clara Xiaoling Chen, University of Illinois at Urbana-Champaign

Kung Chen, University of Nebraska - Lincoln

Peter Chen, Hong Kong University of Science and Technology

Qi Chen, Duke University

Shuping Chen, The University of Texas at Austin

Xia Chen, University of Wisconsin - Madison

Agnes Cheng, Louisiana State University

Shijun Cheng, University of Maryland

Jong-Hag Choi, Seoul National University

Margaret Christ, The University of Georgia

Peter Christensen, Aarhus University

Ted Christensen, Brigham Young University

Wai-Fong Chua, The University of New South Wales

Continued 
Hyeesoo (Sally) Chung, Arizona State University - West

Bryan Church, Georgia Institute of Technology

Peter Clarkson, University of Queensland

Shana Clor-Proell, University of Wisconsin - Madison

Daniel Cohen, New York University

Dan Collins, The University of Iowa

Carlos Corona, The University of Texas at Austin

Masako Darrough, City University of New York - Baruch College

Somnath Das, University of Illinois at Chicago

Sudipto Dasgupta, Hong Kong University of Science and Technology

Angela Davis, University of Oregon

Gus De Franco, University of Toronto

Henri Dekker, Vrije University Amsterdam

Joel Demski, University of Florida

Aiyesha Dey, University of Minnesota

Ilia Dichev, Emory University

John Dickhaut, Chapman University

J. Richard Dietrich, The Ohio State University

Shane Dikolli, Duke University

Ming Dong, York University

Jeffrey Doyle, Utah State University

Julia D'Souza, Cornell University

Scott Dyreng, Duke University

Christine Earley, Providence College

David Easley, Cornell University

Frank Ecker, Duke University

Merle Ederhof, University of Michigan

Eti Einhorn, Tel Aviv University

Randal Elder, Syracuse University

W. Brooke Elliott, University of Illinois at Urbana-Champaign

David Erkens, University of Southern California

Michael Ettredge, University of Kansas

Diana Falsetta, University of Miami

Qintao Fan, University of California, Berkeley

C. Edward Fee, Michigan State University

Bill Felix, University of Arizona

Mei Feng, University of Pittsburgh

Andrew Ferguson, University of Technology Sydney

Fabrizio Ferri, New York University

Rebecca Files, The University of Texas at Dallas

Urs Fischbacher, University of Konstanz

Joseph Fisher, Indiana University

Continued 
Mary Margaret Frank, University of Virginia

Richard Frankel, Washington University at St. Louis

Pingyang Gao, The University of Chicago

Jon Garfinkel, The University of Iowa

Jennifer Gaver, The University of Georgia

Lisa Milici Gaynor, University of South Florida

Weili Ge, University of Washington

Marshall Geiger, University of Richmond

Aloke Ghosh, City University of New York - Baruch College

Michael Gibbs, The University of Chicago

Dan Givoly, The Pennsylvania State University

Guojin Gong, The Pennsylvania State University

Elizabeth Gordon, Temple University

Severin Grabski, Michigan State University

Jeffery Gramlich, University of Southern Maine

Audrey Gramling, Kennesaw State University

Barbara Murray Grein, Drexel University

Paul Griffin, University of California, Davis

Zhaoyang Gu, University of Minnesota

Wayne Guay, University of Pennsylvania

Ferdinand Gul, The Hong Kong Polytechnic University

Sanjay Gupta, Michigan State University

Ilan Guttman, Stanford University

Charles Hadlock, Michigan State University

Jane Hamilton, LaTrobe University

Jackie Hammersley, The University of Georgia

Michelle Hanlon, Massachusetts Institute of Technology

Bruce Haslem, Florida State University

John Hassell, Indiana University - Indianapolis

Richard Hatfield, University of Alabama

Rachel Hayes, University of Utah

Carla Hayn, University of California, Los Angeles

Gary Hecht, Emory University

Frank Heflin, Florida State University

Bill Heninger, Brigham Young University

Karen Hennes, University of Oklahoma

Don Herrmann, Oklahoma State University

Max Hewitt, Indiana University

Stephen Hillegeist, INSEAD

Jessen Hobson, University of Illinois at Urbana-Champaign

Leslie Hodder, Indiana University

Vicky Hoffman, University of Pittsburgh

Continued 
Rani Hoitash, Bentley University

Udi Hoitash, Northeastern University

Lori Holder-Webb, Western New England College

Keith Houghton, Australian National University

Paul Hribar, The University of Iowa

John Hughes, University of California, Los Angeles

Kai Wai Hui, Hong Kong University of Science and Technology

Mingyi Hung, University of Southern California

David Hurtt, Baylor University

Mark Huson, University of Alberta

Amy Hutton, Boston College

Lee-Seok Hwang, Seoul National University

Yuhchang Hwang, Arizona State University

Troy Hyatt, Boise State University

Paul Irvine, The University of Georgia

Alan Jagolinzer, Stanford University

Karim Jamal, University of Alberta

Surya Janakiriman, University of Texas at Dallas

Nicole Jenkins, Vanderbilt University

Ross Jennings, The University of Texas at Austin

Kevan Jensen, University of Oklahoma

John (Xuefeng) Jiang, Michigan State University

W. Bruce Johnson, The University of Iowa

Derek Johnston, Colorado State University

Bjorn Jorgensen, University of Colorado at Boulder

Paul Kalyta, McGill University

Sok-Hyon Kang, The George Washington University

Tony Kang, Oklahoma State University

Ron Kasznik, Stanford University

Sharon Katz, Columbia University

Elizabeth Keating, Boston College

Mozaffar Khan, University of Minnesota

Jeong-Bon Kim, City University of Hong Kong

Oliver Kim, University of Maryland

Michael Kinney, Texas A\&M University

Sandy Klasa, University of Arizona

Ken Klassen, University of Waterloo

Kalin Kolev, Yale University

Gopal Krishnan, Lehigh University

Jagan Krishnan, Temple University

Linda Krull, University of Oregon

Xi (Jason) Kuang, Georgia Institute of Technology

Continued 
Susan Kulp, The George Washington University

Soo Young Kwon, Korea University

Ryan LaFond, BlackRock, Inc.

Richard Lambert, University of Pennsylvania

Wayne Landsman, University of North Carolina at Chapel Hill

Mark Lang, University of North Carolina at Chapel Hill

Christian Laux, Goethe University

Volker Laux, University of Texas at Austin

Charles Lee, Stanford University

Yen-Jung Lee, National Taiwan University

Craig Lefanowicz, University of Virginia

Clive Lennox, Nanyang Technological University

Andrew Leone, University of Miami

Christian Leuz, The University of Chicago

Baruch Lev, New York University

Edward X. Li, University of Rochester

Laura Yue Li, University of Illinois at Urbana-Champaign

Oliver Li, University of Arizona

Siqi Li, Santa Clara University

$\mathrm{Xu} \mathrm{Li}$, Lehigh University

Yue Li, University of Toronto

Pierre Liang, Carnegie Mellon University

Woody Liao, University of California, Riverside

Anne Lillis, University of Melbourne

Marlys Lipe, University of Oklahoma

Robert Lipe, University of Oklahoma

Petro Lisowsky, University of Illinois at Urbana-Champaign

Chao-Shin Liu, University of Notre Dame

Jing Liu, University of California, Los Angeles

Josh Livnat, New York University

Kin Lo, University of British Columbia

Gerald Lobo, University of Houston

Tom Lopez, University of Alabama

Ken Lorek, Northern Arizona University

Tim Loughran, University of Notre Dame

Henock Louis, The Pennsylvania State University

Tong Lu, University of Houston

Yvonne Lu, Lehigh University

Russell Lundholm, University of Michigan

Luann Lynch, University of Virginia

Victor Maas, University of Amsterdam

Mario Maletta, Northeastern University

Continued 
Appendix, TAR Ad Hoc Reviewers from June 1, 2009 - May 31, 2010, continued

Xiumin Martin, Washington University at St. Louis

Michal Matějka, Arizona State University

Zoltan Matolcsy, University of Technology Sydney

Ella Mae Matsumura, University of Wisconsin - Madison

Steven Matsunaga, University of Oregon

Elaine Mauldin, University of Missouri - Columbia

Bill Mayew, Duke University

Cheri Mazza, Fordham University

Mary Lea McAnally, Texas A\&M University

Annie McGowan, Texas A\&M University

Sean McGuire, Texas A\&M University

John McInnis, The University of Texas at Austin

James McKeown, The Pennsylvania State University

Maureen McNichols, Stanford University

Nahum Melumad, Columbia University

Krishnopal Menon, Boston University

Molly Mercer, DePaul University

Richard Mergenthaler, The University of Iowa

William Messier, University of Nevada, Las Vegas

Brian Miller, Indiana University

Jeffrey Miller, University of Notre Dame

Birendra Mishra, University of California, Riverside

Stephen Moehrle, University of Missouri - St. Louis

Frank Moers, Maastricht University

Emad Mohammad, McMaster University

Kimberly Moreno, Northeastern University

Richard Morton, Florida State University

Karl Muller, The Pennsylvania State University

Linda Myers, University of Arkansas

Mark Myring, Ball State University

Nandu Nagarajan, University of Pittsburgh

Vic Naiker, The University of Auckland

Dhananjay Nanda, University of Miami

Gordian Ndubizu, Drexel University

Alexander Nekrasov, University of California, Irvine

Mark Nelson, Cornell University

Andrew Newman, University of Pittsburgh

Jeffrey Ng, Massachusetts Institute of Technology

Terence Ng, Nanyang Technological University

D. Craig Nichols, Cornell University

Christine Nolder, Bentley University

David North, University of Richmond

Continued 
Patricia O'Brien, University of Waterloo

Maria Ogneva, Stanford University

Steven Orpurt, Pepperdine University

Jaime Ortega, Universidad Carlos III de Madrid

Linda Parsons, University of Alabama

Evelyn Patterson, Indiana University - Indianapolis

Kenneth Peasnell, Lancaster University

Raynolde Pereira, University of Missouri - Columbia

Gary Peters, University of Arkansas

Michael Peters, Villanova University

Christine Petrovits, New York University

Ray Pfeiffer, Texas Christian University

Marc Picconi, Indiana University

Arianana Pinello, Georgia State University

Matt Pinnuck, University of Melbourne

Mini Pizzini, Southern Methodist University

George Plesko, University of Connecticut

Elizabeth Plummer, Texas Christian University

Susan Porter, University of Virginia

Gordon Potter, Cornell University

Grace Pownall, Emory University

Doug Prawitt, Brigham Young University

Madhav Rajan, Stanford University

Dasaratha Rama, Florida International University

Kartik Raman, Bentley University

K. Ramesh, Rice University

Sunderesh Ramnath, University of Miami

Srinivasan Rangan, University of California, Davis

Bill Rankin, Colorado State University

Susan Ravenscroft, Iowa State University

Korok Ray, Georgetown University

David Reeb, Temple University

Lynn Rees, Texas A\&M University

Sonja Olhoft Rego, The University of Iowa

Ken Reichelt, Louisiana State University

Robert Resutek, Dartmouth College

J. Kenneth Reynolds, Indiana University

David Ricchiute, University of Notre Dame

Jay Rich, Illinois State University

Ed Riedl, Harvard University

Andrea Alston Roberts, University of Virginia

Leslie Robinson, Dartmouth College

Continued 
Appendix, TAR Ad Hoc Reviewers from June 1, 2009 - May 31, 2010, continued

Jonathan Rogers, The University of Chicago

Jacob Rose, University of New Hampshire

Joshua Rosett, Claremont McKenna College

Brian Rountree, Rice University

Casey Rowe, Purdue University

Sugata Roychowdhury, Boston College

Tjomme Rusticus, Northwestern University

Stephen Ryan, New York University

Gil Sadka, Columbia University

Steve Salterio, Queen's University

Maria Sanchez, Rider University

Tatiana Sandino, University of Southern California

Srinivasan Sankaraguruswamy, National University of Singapore

Richard Saouma, University of California, Los Angeles

Haresh Sapra, The University of Chicago

Andrew Schmidt, Columbia University

Susan Scholz, University of Kansas

Joseph Schultz, Arizona State University

Steven Schwartz, State University of New York - Binghamton

Dan Segal, Interdisciplinary Center Herzliya

Frank Selto, University of Colorado at Boulder

Partha Sengupta, George Mason University

Nick Seybert, University of Maryland

Doug Shackelford, University of North Carolina at Chapel Hill

Ron Shalev, Washington University at St. Louis

Philip Shane, University of Colorado at Boulder

Divesh Sharma, Florida International University

Kenneth Shaw, University of Missouri - Columbia

Min Shen, George Mason University

Terry Shevlin, University of Washington

Michael Shields, Michigan State University

Jae Yong Shin, Seoul National University

Pervin Shroff, University of Minnesota

Stephanie Sikes, University of Pennsylvania

Paul Simko, University of Virginia

Roger Simnett, The University of New South Wales

Dan Simunic, University of British Columbia

Jason Smith, University of Nevada, Las Vegas

Michael Smith, Boston University

Naomi Soderstrom, University of Colorado at Boulder

Brian Spilker, Brigham Young University

Sri Sridhar, Northwestern University

Continued 
Dhinu Srinivasan, University of Pittsburgh

Suraj Srinivasan, Harvard University

Anup Srivastava, Northwestern University

Paul Steinbart, Arizona State University

Doug Stevens, Florida State University

Don Stokes, Monash University

Roland Strausz, Humboldt University - Berlin

Stephen Stubben, University of North Carolina at Chapel Hill

Scott Summers, Brigham Young University

Amy Sun, The Pennsylvania State University

Yan Sun, Saint Louis University

Jayanthi Sunder, Northwestern University

Shyam V. Sunder, Northwestern University

Shyam Sunder, Yale University

Ed Swanson, Texas A\&M University

Vicki Tang, Georgetown University

Bill Tayler, Emory University

Siew-Hong Teoh, University of California, Irvine

Jane Thayer, The University of Georgia

Robert Trezevant, University of Southern California

Jennifer Wu Tucker, University of Florida

Wim Van der Stede, London School of Economics

Laurence van Lent, Tilburg University

Ann Vanstraelen, Maastricht University

Florin Vasvari, London Business School

Uma Velury, University of Delaware

Ramgopal Venkataraman, Southern Methodist University

Raghu Venugopalan, University of Illinois at Urbana-Champaign

Rodrigo Verdi, Massachusetts Institute of Technology

Robert Verrecchia, University of Pennsylvania

Cynthia Vines, University of Kentucky

Gnanakumar Visvanathan, George Mason University

Alfred Wagenhofer, University of Graz

James Wahlen, Indiana University

Dechun Wang, Texas A\&M University

Isabel Wang, Michigan State University

Shiing-Wu Wang, University of Southern California

Xue (Sue) Wang, Emory University

Gregory Waymire, Emory University

Connie Weaver, Texas A\&M University

Alan Webb, University of Waterloo

Dan Weiss, Tel Aviv University

Continued 
Appendix, TAR Ad Hoc Reviewers from June 1, 2009 - May 31, 2010, continued

Michael Welker, Queen's University

Scott Whisenant, University of Houston

Sally Widener, Rice University

Heather Wier, University of Alberta

T. Jeffrey Wilks, Brigham Young University

Michael Willenborg, University of Connecticut

David Williams, The Ohio State University

Michael Williams, Gradient Analytics, Inc.

Michael Williamson, The University of Texas at Austin

Ryan Wilson, The University of Iowa

Wendy Wilson, Southern Methodist University

Jennifer Winchel, University of South Carolina

Christopher Wolfe, Texas A\&M University

Franco Wong, University of Toronto

Donghui $\mathrm{Wu}$, Hong Kong Polytechnic University

Joanna Wu, University of Rochester

Martin $\mathrm{Wu}$, University of Illinois at Urbana-Champaign

Anne Wyatt, University of Queensland

Jingyoung Park Wynn, Louisiana Tech University

Peter Wysocki, University of Miami

Hong Xie, University of Kentucky

David Yermack, New York University

Michelle Yetman, University of California, Davis

Robert Yetman, University of California, Davis

Ping Eric Yeung, The University of Georgia

Han Yi, University of Oklahoma

Lance Young, University of Washington

Yong Yu, The University of Texas at Austin

Tzachi Zach, The Ohio State University

Guochang Zhang, Hong Kong University of Science and Technology

Ivy Zhang, University of Minnesota

Jieying Zhang, University of Southern California

May H. Zhang, University of Missouri - Columbia

Ping Zhang, University of Toronto

$X$. Frank Zhang, Yale University

Yuan Zhang, Columbia University

Yue May Zhang, Northeastern University

Yun Zhang, Duke University

Yijiang Zhao, American University

Amir Ziv, Columbia University 